\title{
Neutralizing antibodies to botulinum neurotoxin type $A$ in aesthetic medicine: five case reports
}

This article was published in the following Dove Press journal:

Clinical, Cosmetic and Investigational Dermatology

17 December 2013

Number of times this article has been viewed

\section{Sebastian Torres' \\ Mark Hamilton ${ }^{2}$ \\ Elena Sanches ${ }^{4}$ \\ Polina Starovatova ${ }^{3}$ \\ Elena Gubanova ${ }^{3}$ \\ Tatiana Reshetnikova ${ }^{5}$ \\ 'Di Stefano Velona Clinic, Catania, Italy; ${ }^{2}$ Hamilton Face Clinic, Dublin, Ireland; ${ }^{3}$ Preventive Medicine \\ Clinic "Vallex M", Moscow, Russia; ${ }^{4}$ EKLAN Co Ltd Medical Center for Aesthetic Correction, Moscow, Russia; ${ }^{5}$ Department of Dermatovenereology and Cosmetology, State Medical University, Novosibirsk, Russia}

Correspondence: Sebastian Torres Chirurgia Maxillofacciale ed Estetica, Di Stefano Velona Clinic, Catania, Italy Tel +39392883 3702

Email storres100@gmail.com
Abstract: Botulinum neurotoxin injections are a valuable treatment modality for many therapeutic indications as well as in the aesthetic field for facial rejuvenation. As successful treatment requires repeated injections over a long period of time, secondary resistance to botulinum toxin preparations after repeated injections is an ongoing concern. We report five case studies in which neutralizing antibodies to botulinum toxin type A developed after injection for aesthetic use and resulted in secondary treatment failure. These results add to the growing number of reports in the literature for secondary treatment failure associated with high titers of neutralizing antibodies in the aesthetic field. Clinicians should be aware of this risk and implement injection protocols that minimize resistance development.

Keywords: aesthetic medicine, botulinum neurotoxin type A, neutralizing antibody, secondary treatment failure

\section{Introduction}

Botulinum neurotoxins are of great interest to the medical community and have wide-ranging applications as pharmaceutical and aesthetic treatments. Over the past 10 years, facial rejuvenation has been revolutionized by the excellent cosmetic results achieved with the use of botulinum toxin type $\mathrm{A}$, such that it is now the top nonsurgical procedure in many countries in the world. ${ }^{1,2}$

As with any therapeutic protein, all botulinum toxins are capable of inducing the formation of immunoglobulin G-neutralizing antibodies with repeated injections. ${ }^{3}$ Conventional botulinum toxin type A is a complex of the $150 \mathrm{kD}$ neurotoxin and other nontoxic complexing proteins. All of these foreign proteins are antigens and have the potential to induce an immune response. Antibodies blocking the pharmacological effects of the botulinum neurotoxin are termed neutralizing antibodies. ${ }^{4}$ Non-neutralizing antibodies do not influence the therapeutic effect, but increase the foreign protein load and potentially increase the immunogenic risk of neutralizing antibody formation. ${ }^{5}$

Most of the information concerning antibody formation relates to the therapeutic use of botulinum toxin, for which there is over 30 years of clinical experience. The incidence of neutralizing antibody formation following treatment with onabotulinumtoxinA (BOTOX ${ }^{\circledR} /$ Vistabel $^{\mathbb{}} /$ Vistabex $^{\circledR}$; Allergan Inc, Irvine, CA, USA), the first botulinum toxin to be marketed, has been significantly reduced, but not eliminated, since its original formulation was changed to reduce the protein load per dose. ${ }^{6,7}$ The prevalence of patients developing neutralizing antibodies after long-term treatment 
with currently approved botulinum toxin type A preparations depends on the condition to be treated (aesthetic or medical) and the dose given (the higher the dose, the higher the risk). Based on the former the global incidence according to literature varies from $0.3-6 \% .^{8-13}$

Much lower doses of botulinum toxin preparations are used in the aesthetic field, but as treatment indications require repeated injections, individuals may be at risk for immunologic reactions with possible formation of neutralizing antibodies and secondary treatment failure. Several papers have reported neutralizing antibodies in this population. ${ }^{14-17}$

There are no published data on the prevalence of nonresponse in the aesthetic field, but as the indications and duration of treatment of botulinum toxin type A increase, likely so will reports of patients who fail therapy after initially responding well. To raise awareness of the possibility of neutralizing antibodies in secondary treatment failure, we report on five patients from our respective centers in whom secondary treatment failure occurred.

\section{Case presentations Case I (Dr Torres)}

A 55-year-old Caucasian woman was initially treated in September 2011 with 33 units (U) of onabotulinumtoxinA $\left(\right.$ Vistabel $^{\circledR}$ ) in the upper third of the face. She received $6 \mathrm{U}$ over three injection points in each orbicularis oculi, $5 \mathrm{U}$ at one injection point in each corrugator muscle, $5 \mathrm{U}$ at one injection point in the procerus, and a total of $6 \mathrm{U}$ over three injection points in the frontalis muscle (one central and two lateral) (Table 1).

The patient experienced almost no response to the first treatment (Figures 1 and 2). At the second visit, in October 2011, she was switched to treatment with 80 Speywood U of abobotulinumtoxinA (Dysport ${ }^{\circledR}$; Ipsen Ltd., Basking Ridge, NJ, USA/Azzalure ${ }^{\circledR}$; Galderma, Paris, France) in the same injection points. A mild response was observed, which lasted 3 months. The patient's serum was tested after the second treatment for the presence of neutralizing antibodies to botulinum toxin type A at a specialized laboratory (Toxogen $\mathrm{GmbH}$, Hannover, Germany). The patient was positive for neutralizing antibodies, although the titers were not very high.

\section{Case 2 (Dr Hamilton)}

Case 2 concerns a 54-year-old Caucasian woman who had been receiving botulinum toxin type A preparations for 2 years. She was initially treated with abobotulinumtoxinA $\left(\right.$ Dysport $\left.^{\circledR}\right)$ in April 2009, when she received 50 Speywood U over five injection points in the glabella, $20 \mathrm{U}$ over ten injection points in the frontalis muscle, $50 \mathrm{U}$ (25 each side) over four injection points in the orbicularis oculi, and $50 \mathrm{U}$ in the jawline, along and below the mandibular line (Table 2). Within the next 4 weeks, she received $50 \mathrm{U}$ over ten injection points in the platysmal bands with two further top-ups in the platysmal bands over the following month (Table 2). Over the course of the year, the woman received three more treatments with abobotulinumtoxinA (Dysport ${ }^{\circledR}$ ) in the glabella, frontalis, orbicularis oculi, and jawline as outlined in Table 2.

In May 2010, the woman received further injections with abobotulinumtoxinA (Dysport ${ }^{\circledR}$ ) in the glabella, frontalis, orbicularis oculi, and platysmal bands (Table 2), but reported that the treatment was not working as well as it had been (Figures 3 and 4). At the next treatment, 6 months later, she was switched to onabotulinumtoxinA $\left(\right.$ BOTOX $\left.^{\circledR}\right)$ (Table 2), but the treatment had little effect. Three months later, the patient returned to treatment with abobotulinumtoxinA $\left(\right.$ Dysport $\left.^{\circledR}\right)$, but reported no effect after 4 weeks. A final treatment with incobotulinumtoxinA (Xeomin ${ }^{\circledR} /$ Bocouture $^{\circledR}$; Merz Pharmaceuticals GmbH, Frankfurt am Main, Germany) was tried 9 months later, but the duration

Table I Case I (female, 55 years, Caucasian) treatment history

\begin{tabular}{|c|c|c|c|c|}
\hline Date & BTX-A preparation & Dosage & Area treated & Number of injection points \\
\hline \multirow[t]{5}{*}{ September 20II } & Vistabel ${ }^{\circledR} /$ Vistabex $^{\circledR}$ & $12 \mathrm{U}$ & $6 U$ in each orbicularis oculi & 3 \\
\hline & & $10 \mathrm{U}$ & $5 \mathrm{U}$ in each corrugator & I \\
\hline & & $5 \cup$ & Procerus & 1 \\
\hline & & $6 U$ & Frontalis & 1 \\
\hline & & & No response to treatment & \\
\hline \multirow[t]{5}{*}{ October 2011 } & Azzalure ${ }^{\circledR}$ & 80 Speywood U & Orbicularis oculi & 3 \\
\hline & & & Corrugator & 1 \\
\hline & & & Procerus & I \\
\hline & & & Frontalis & 1 \\
\hline & & & Duration of effect: 45 days & \\
\hline
\end{tabular}

Notes: Vistabel ${ }^{\circledast} /$ Vistabex $^{\circledR}$ : Allergan Inc, Irvine, CA, USA. Azzalure ${ }^{\circledR}$ : Galderma, Paris, France.

Abbreviations: BTX-A, botulinum toxin type $A ; U$, units. 

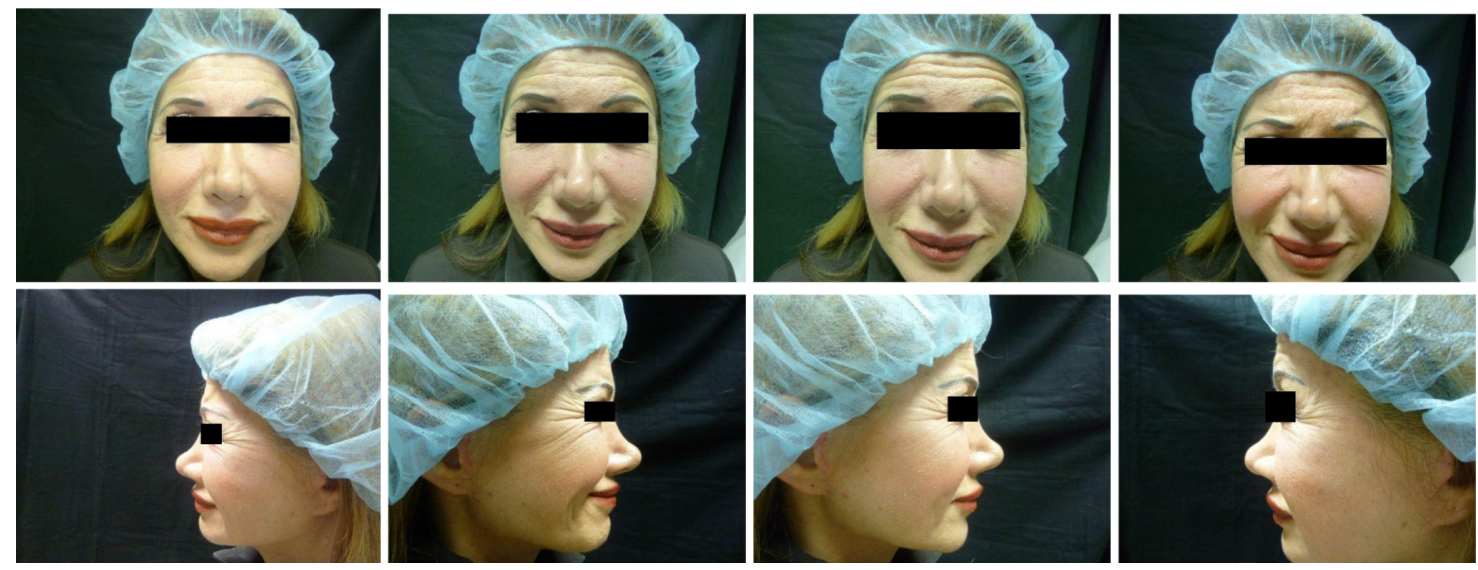

Figure I Case I: pretreatment photos.

of effect was only 2 weeks. The patient tested positive (++) for antibodies to botulinum toxin type A. At this time, no further therapy is planned.

\section{Case 3 (Dr Sanches)}

A 41-year-old Caucasian woman was initially treated for hyperhidrosis in 2006 with $100 \mathrm{U}$ of onabotulinumtoxinA $\left(\right.$ BOTOX $^{\circledR}$ ) (Table 3). The treatment effect lasted 5 months. In 2009, the woman received a further $100 \mathrm{U}$ of onabotulinumtoxinA for hyperhidrosis and an additional $50 \mathrm{U}$ over ten injection points in the frontalis muscle, four injection points in the corrugator muscles, one injection point in the procerus, and four injection points in each orbicularis oculi muscle. The treatment effect was 2-3 months. In 2010, she received a repeat treatment for hyperhidrosis with $150 \mathrm{U}$ of onabotulinumtoxinA with clinical effect lasting 2-3 months. At her last treatment for hyperhidrosis, she received 500 $\mathrm{U}$ of abobotulinumtoxinA (Dysport ${ }^{\circledR}$ ) with a duration of effect of only 1.5 months. The patient was considered a nonresponder, as the treatment effect was very weak and the sweating partially remained. The patient tested positive (++) for antibodies to botulinum toxin type A.

\section{Case 4 (Dr Gubanova)}

The patient in the fourth case study was a 43-year-old Caucasian woman who had received botulinum toxin type A for facial rejuvenation over a period of 8 years, starting in 2004. During this time she had received a total of $1,000 \mathrm{U}$ of abobotulinumtoxinA (Dysport ${ }^{\mathbb{R}}$ ) over eight injection sessions, with injection points in the frontalis, corrugator, procerus, orbicularis oculi, and platysmal bands (Table 4). For the first 3 years, the duration of effect lasted 6-8 months. However, after 2007, treatment effects could not be observed after 3 months. Results of antibody titers were high positive (++).

\section{Case 5 (Dr Reshetnikova)}

The final case study involved a 38-year-old European male. His treatment began in 2010 when he received $120 \mathrm{U}$ of
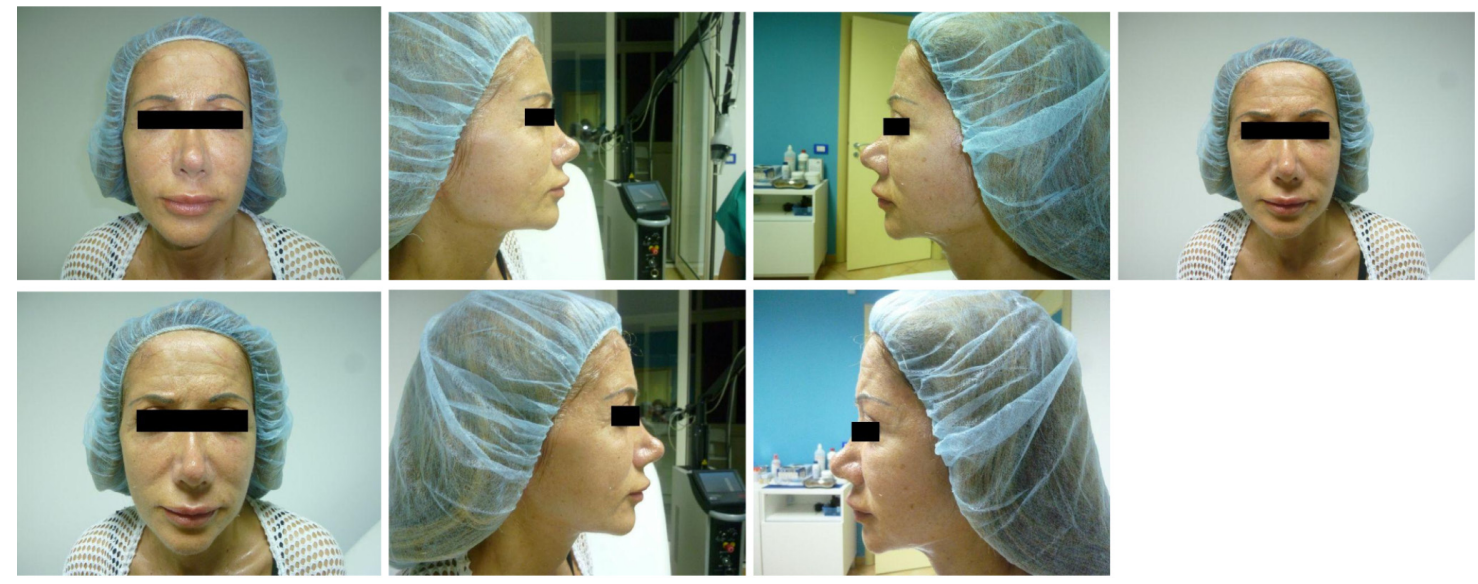

Figure 2 Case I: 2 weeks posttreatment photos. 
Table 2 Case 2 (female, 54 years, Caucasian) treatment history

\begin{tabular}{|c|c|c|c|c|}
\hline Date & BTX-A preparation & Dosage & Area treated & Number of injection points \\
\hline \multirow[t]{4}{*}{ April 2, 2009} & Dysport $^{\circledR}$ & 50 Speywood U & Glabella & 5 \\
\hline & & $20 U$ & Frontalis & 10 \\
\hline & & $50 \mathrm{U}$ & Orbicularis oculi ( $25 \mathrm{U}$ in each) & 4 \\
\hline & & $50 \mathrm{U}$ & Jawline & 10 \\
\hline April 23, 2009 & Dysport $^{\circledR}$ & $50 \cup$ & Platysmal bands & 10 \\
\hline May 4, 2009 & Dysport $^{\circledR}$ & $25 \cup$ & Platysmal bands & 10 \\
\hline \multirow[t]{2}{*}{ June 4, 2009} & Dysport $^{\circledR}$ & $20 \mathrm{U}$ & Platysmal bands & \\
\hline & & $20 \mathrm{U}$ & Frontalis & 5 \\
\hline \multirow[t]{4}{*}{ July 30, 2009} & Dysport $^{\circledR}$ & $30 u$ & Glabella & 5 \\
\hline & & $20 U$ & Frontalis & 5 \\
\hline & & $50 U$ & Orbicularis oculi ( $25 \mathrm{U}$ in each) & 4 \\
\hline & & $50 U$ & Jawline & 10 \\
\hline \multirow[t]{4}{*}{ October I5, 2009} & Dysport $^{\circledR}$ & $50 \cup$ & Glabella & 5 \\
\hline & & $20 \mathrm{U}$ & Frontalis & 5 \\
\hline & & $50 \mathrm{U}$ & Orbicularis oculi (25 U in each) & 4 \\
\hline & & $50 \mathrm{U}$ & Jawline & 10 \\
\hline \multirow[t]{3}{*}{ December 17, 2009} & Dysport $^{\circledR}$ & $40 \mathrm{U}$ & Glabella & 5 \\
\hline & & $20 U$ & Frontalis & 5 \\
\hline & & $30 \mathrm{U}$ & Orbicularis oculi ( $15 \mathrm{U}$ in each) & \\
\hline \multirow[t]{4}{*}{ May 27,2010} & Dysport $^{\circledR}$ & $50 U$ & Glabella & 5 \\
\hline & & $30 \mathrm{U}$ & Frontalis & 5 \\
\hline & & $50 \mathrm{U}$ & Orbicularis oculi (25 U in each) & 4 \\
\hline & & $50 \mathrm{U}$ & Platysmal bands & \\
\hline \multirow[t]{6}{*}{ December 4, 2010} & BOTOX ${ }^{\circledR}$ & $21 U$ & Glabella & 5 \\
\hline & & $12 \mathrm{U}$ & Frontalis & \\
\hline & & $20 U$ & Orbicularis oculi ( $10 \mathrm{U}$ in each) & \\
\hline & & $4 \cup$ & Depressor anguli oris ( $2 U$ in each) & \\
\hline & & $3 \cup$ & Mentalis & \\
\hline & & $10 \mathrm{U}$ & Jawline & \\
\hline \multirow[t]{3}{*}{ March 3I, 20II } & Dysport $^{\circledR}$ & 70 Speywood U & Glabella & 5 \\
\hline & & $50 \mathrm{U}$ & Frontalis & 10 \\
\hline & & $70 u$ & Orbicularis oculi (35 U in each) & 4 per side ( 8 total) \\
\hline \multirow[t]{3}{*}{ December 15, 20II } & Xeomin $^{\circledR}$ & $26 U$ & Glabella & 5 \\
\hline & & $17 U$ & Frontalis & 12 \\
\hline & & $26 U$ & Orbicularis oculi ( $13 \mathrm{U}$ in each) & 4 per side ( 8 total) \\
\hline
\end{tabular}

Notes: Dysport ${ }^{\circledR}$ : Ipsen Ltd, Basking Ridge, NJ, USA. BOTOX ${ }^{\circledR}$ : Allergan Inc, Irvine, CA, USA. Xeomin ${ }^{\circledR}$ : Merz Pharmaceuticals GmbH, Frankfurt am Main, Germany. Abbreviations: BTX-A, botulinum toxin type $A ; U$, units.

abobotulinumtoxinA (Dysport ${ }^{\mathbb{R}}$ ) over three injection points each in the frontalis, corrugator, and procerus (Table 5). The initial duration of effect was 6 months. In 2011, he received $200 \mathrm{U}$ in the same injection points with a duration of effect of only 2 months. His final treatment, in 2012, with $250 \mathrm{U}$ of Dysport ${ }^{\circledR}$ produced no effect. Results of antibody titers were high positive $(++)$.

\section{Discussion}

The patients in these case reports all developed secondary treatment failure and tested positive for neutralizing antibodies by the mouse phrenic nerve hemidiaphragm assay (HDA), suggesting that the cause of the therapy failure was neutralizing antibodies to botulinum toxin type A. The factors that contribute to neutralizing antibody formation against botulinum toxin type A have not been well characterized. The data that do exist relate to the use of the toxin for therapeutic indications and suggest that two factors, in particular, are important: protein load per effective dose and frequency of exposure.

The results of several retrospective studies suggest that the association between higher protein exposure and increased risk of antibody formation holds true for botulinum toxins. ${ }^{18,19}$ For example, in a retrospective comparison of 20 patients with cervical dystonia who developed antibodies and 22 who did not, a link was found between the mean dose per treatment session, total cumulative dose, and the development of neutralizing antibodies. ${ }^{19}$ This has also been illustrated by the five-fold reduction in protein load with the current onabotulinumtoxinA compared with the original preparation. ${ }^{6,7}$ 

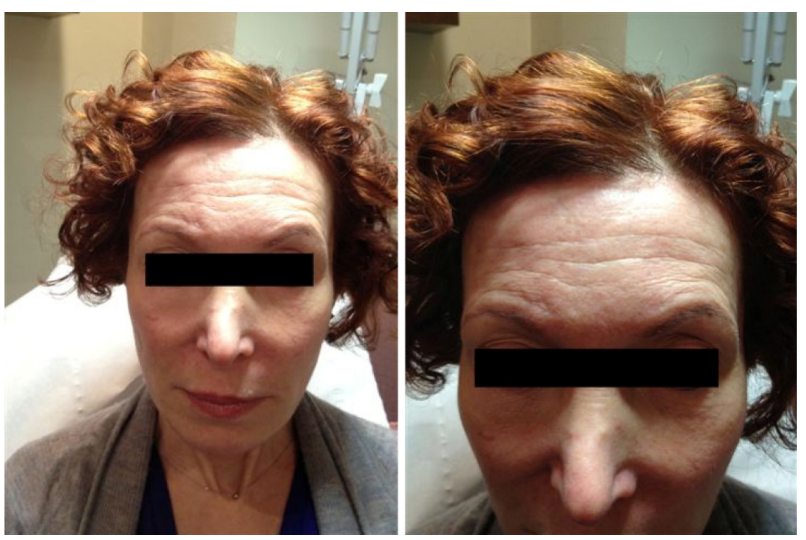

Figure 3 Case 2: pretreatment photos.

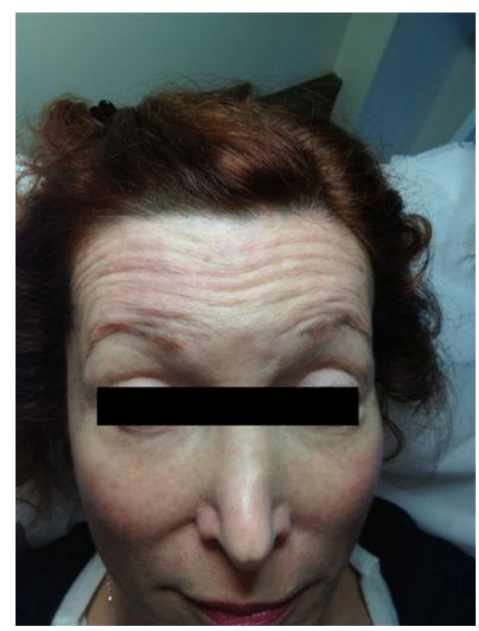

Figure 4 Case 2: 2 weeks posttreatment photo.

Frequent injections of a foreign protein increase the body's immune response and may also increase the risk of antibody formation. In one retrospective study of patients with torticollis, eight of 76 patients (10.5\%) stopped responding to treatment. Compared to nonresistant patients from the same cohort, these eight patients had received more frequent injections, had more top-up injections $2-3$ weeks after an initial injection, and had received higher doses of botulinum toxin per treatment. ${ }^{18}$

That neutralizing antibodies can directly cause resistance has been shown in a case study in which a patient with severe dystonia, secondary resistance, and detectable neutralizing antibodies was treated with repeated plasma exchange and depletion of serum antibodies; subsequent treatment with the same botulinum toxin type was successful. ${ }^{20}$

However, antibody titers required to cause resistance to botulinum toxin have not been defined, and immune responses can differ between patients. Thus, the formation of neutralizing antibodies may have no effect on treatment or may result in partial or complete clinical unresponsiveness to botulinum toxin type A..$^{21,22}$ While both physicians and patients should be aware of the possibility that immunological resistance can occur after repeated botulinum toxin type A injections, it is important to determine the underlying cause. In addition to development of neutralizing antibodies, there are several other possible reasons for loss of response to botulinum neurotoxins, including misplaced toxin, suboptimal dosing, administration of toxin that has been denatured by improper storage or handling, and errors in reconstitution.

A declining clinical response to botulinum toxin over several injection sessions, as was the case in our case reports, should raise suspicion and trigger investigation into whether neutralizing antibodies are being produced. This is important as, if resistance has developed, patients will not benefit from repeated toxin injections or from switching to another botulinum toxin type A product. An antibody response may develop to any toxin-associated proteins, and studies are required to determine which are the most important. Laboratory screening tests such as enzyme-linked immunosorbent assay and fluorescence immunoassay are not able to distinguish between neutralizing and non-neutralizing antibodies. The only FDA-approved assay for the detection of neutralizing antibodies is the HDA, but few laboratories

Table 3 Case 3 (female, 4 I years, Caucasian) treatment history

\begin{tabular}{|c|c|c|c|c|c|}
\hline Date & BTX-A preparation & Dosage & Area treated & $\begin{array}{l}\text { Number of } \\
\text { injection points }\end{array}$ & Duration of effect \\
\hline 2006 & BOTOX ${ }^{\circledR}$ & $100 \mathrm{U}$ & Hyperhidrosis & 40 & 5 months \\
\hline \multirow[t]{5}{*}{2009} & BOTOX ${ }^{\circledR}$ & I50 U & Frontalis & 10 & $2-3$ months \\
\hline & & & Corrugator & 4 & \\
\hline & & & Procerus & 1 & \\
\hline & & & Orbicularis oculi & 8 & \\
\hline & & & Hyperhidrosis & 40 & \\
\hline 2010 & BOTOX ${ }^{\circledR}$ & I50 U & Hyperhidrosis & 40 & $2-3$ months \\
\hline $201 \mathrm{I}-2012$ & Dysport $^{\circledR}$ & $650 \cup$ & Hyperhidrosis & 40 & I.5 months \\
\hline
\end{tabular}

Notes: BOTOX ${ }^{\circledR}$ : Allergan Inc, Irvine, CA, USA. Dysport ${ }^{\circledR}$ : Ipsen Ltd, Basking Ridge, NJ, USA.

Abbreviations: BTX-A, botulinum toxin type $A ; U$, units. 
Table 4 Case 4 (female, 43 years, Caucasian, total dose I,000 U) treatment history

\begin{tabular}{|c|c|c|c|c|c|}
\hline Date & BTX-A preparation & Dosage & Area treated & $\begin{array}{l}\text { Number of } \\
\text { injection points }\end{array}$ & Duration of effect \\
\hline \multirow[t]{2}{*}{ 2004-2005 } & Dysport $^{\circledR}$ & $80 U \times 2$ & Frontalis (30 U) & 4 & 6-8 months \\
\hline & & & Glabella (50 U) & 5 & \\
\hline \multirow[t]{2}{*}{2006} & Dysport $^{\circledR}$ & $100 \mathrm{U}$ & Frontalis (30 U) & 4 & 5-6 months \\
\hline & & & Glabella (70 U) & 3 & \\
\hline \multirow[t]{2}{*}{2007} & Dysport $^{\circledR}$ & $120 \mathrm{U}$ & Frontalis (40 U) & 4 & 4 months \\
\hline & & & Glabella (80 U) & 3 & \\
\hline \multirow[t]{2}{*}{ 2008-2009 } & Dysport ${ }^{\circledR}$ & $130 U \times 2$ & Glabella (90 U) & 3 & 3 months \\
\hline & & & Orbicularis oculi (40 U) & 4 & \\
\hline \multirow[t]{2}{*}{2010} & Dysport $^{\circledR}$ & $150 \mathrm{U}$ & Glabella (90 U) & 3 & 3 months \\
\hline & & & Orbicularis oculi $(60 \mathrm{U})$ & 4 & \\
\hline \multirow[t]{3}{*}{2011} & Dysport $^{\circledR}$ & $210 U$ & Frontalis (40 U) & 4 & 3 months \\
\hline & & & Glabella (90 U) & 3 & \\
\hline & & & Orbicularis oculi (80 U) & 4 & \\
\hline
\end{tabular}

Note: Dysport ${ }^{\circledR}$ : Ipsen Ltd, Basking Ridge, NJ, USA.

Abbreviations: BTX-A, botulinum toxin type $A ; U$, units.

are equipped to perform this test. Furthermore, the HDA may result in detection of subclinical antibody titers that do not result in treatment failure. Promising new assay methods are appearing, ${ }^{23}$ and should be pursued so that physicians have access to a test that is simple, fast, and economical. Given the limitations of botulinum toxin antibody testing to date, it is likely that the true incidence of secondary resistance to botulinum toxin preparations is significantly underestimated. This is compounded by the fact that few aesthetic clinicians, particularly non-physician injectors, are familiar with the problem of neutralizing antibodies and will continue to treat with a higher dose or by switching to another therapy.

Our report shows that secondary treatment failure can occur with botulinum toxin type A for aesthetic treatment in routine clinical practice. Limited information is available on whether neutralizing antibodies resolve over time and, consequently, whether attempts at reinjection should be made after a prolonged period. In this situation, the immunological quality of the botulinum toxin used is important. IncobotulinumtoxinA is a botulinum neurotoxin free of complexing proteins with low antigenicity.

In addition to selecting a product with a low risk of antigenicity, it is important to establish good practice to minimize the risk of neutralizing antibodies developing. Most experts currently recommend using the smallest dose that achieves the desired clinical effect, avoiding booster injections, and waiting at least 3 months between treatments. As physicians gain experience with a given product, they may be able to better select the lowest effective dose for their patients and treat at the longest possible injection intervals. In the future, effective botulinum toxin type A treatment may be restored in immunoresistant patients by epitope-selective modulation of antibody responses. ${ }^{24,25}$

\section{Conclusion}

The case studies presented in this report show that neutralizing antibodies can occur even with the low doses of botulinum

Table 5 Case 5 (male, 38 years, Caucasian) treatment history

\begin{tabular}{llllll}
\hline Date & BTX-A preparation & Dosage & Area treated & $\begin{array}{l}\text { Number of } \\
\text { injection points }\end{array}$ & Duration of effect \\
\hline 2010 & Dysport $^{\circledR}$ & $120 U$ & Frontalis & 3 & 6 months \\
& & & Corrugator & 3 & 2 months \\
2011 & Dysport $^{\circledR}$ & $200 U$ & Procerus & 3 & No effect \\
& & & Frontalis & 5 & \\
& & & Corrugator & 6 & 1 \\
\end{tabular}

Note: Dysport ${ }^{\circledR}$ : Ipsen Ltd, Basking Ridge, NJ, USA. 
toxin type A used in aesthetic practice and may result in secondary treatment failure. Published literature in this area is sparse, and much work is required to determine the true prevalence of resistance in the aesthetic field as well as the nature of the neutralizing antibodies. For this to occur, the issue must be raised with physicians and a simple laboratory test developed to test for resistance as soon as secondary treatment failure occurs. Until then, all aesthetic clinicians should consider choosing a toxin with the least immunogenic potential and become familiar with best practices for minimizing the risk of neutralizing antibodies developing.

\section{Disclosure}

The authors report no conflicts of interest in this work.

\section{References}

1. $15^{\text {th }}$ Annual Cosmetic Surgery National Data Bank Statistics. New York, NY: The American Society for Aesthetic Plastic Surgery (ASAPS); 2012. Available from: http://www.surgery.org/sites/default/files/ASAPS-2011Stats.pdf. Accessed. September 30, 2013.

2. Total Procedures For Top 25 Countries. Available from: http://www. isaps.org/files/html-contents/Raw_data_Survey2009.pdf. International Society of Aesthetic Plastic Surgeons; 2009. Accessed Sep 2012.

3. Göschel H, Wohlfarth K, Frevert J, Dengler R, Bigalke H. Botulinum A toxin therapy: neutralizing and nonneutralizing antibodies - therapeutic consequences. Exp Neurol. 1997;147:96-102.

4. Dressler D. Clinical presentation and management of antibody-induced failure of botulinum toxin therapy. Mov Disord. 2004;19 Suppl 8: S92-S100.

5. Frevert J, Dressler D. Complexing proteins in botulinum toxin type A drugs: a help or a hindrance? Biologics. 2010;4:325-332.

6. Aoki KR, Merlino G, Spanoyannis AF, Wheeler LA. BOTOX (botulinum toxin type A) purified neurotoxin complex prepared from the new bulk toxin retains the same preclinical efficacy as the original but with reduced antigenicity. Neurology. 1999;52(Suppl 2):A521-A522.

7. Jankovic J, Vuong KD, Ahsan J. Comparison of efficacy and immunogenicity of original versus current botulinum toxin in cervical dystonia. Neurology. 2003;60:1186-1188.

8. Yablon SA, Brashear A, Gordon MF, et al. Formation of neutralizing antibodies in patients receiving botulinum toxin type $\mathrm{A}$ for treatment of poststroke spasticity: a pooled-data analysis of three clinical trials. Clin Ther. 2007;29:683-690.

9. Brin MF, Comella CL, Jankovic J, Lai F, Naumann M; CD-017 BoNTA Study Group. Long-term treatment with botulinum toxin type A in cervical dystonia has low immunogenicity by mouse protection assay. Mov Disord. 2008;23:1353-1360.
10. Schulte-Baukloh H, Bigalke H, Miller K, et al. Botulinum neurotoxin type A in urology: antibodies as a cause of therapy failure. Int J Urol. 2008:15:407-415.

11. Mohammadi B, Buhr N, Bigalke H, Krampfl K, Dengler R, Kollewe K. A long-term follow-up of botulinum toxin A in cervical dystonia. Neurol Res. 2009;31:463-466.

12. Müller K, Mix E, Adib Saberi F, Dressler D, Benecke R. Prevalence of neutralising antibodies in patients treated with botulinum toxin type A for spasticity. J Neural Transm. 2009;116:579-585.

13. Naumann M, Carruthers A, Carruthers J, et al. Meta-analysis of neutralizing antibody conversion with onabotulinumtoxinA $\left(\right.$ BOTOX $\left.^{\circledR}\right)$ across multiple indications. Mov Disord. 2010;25:2211-2218.

14. Borodic G. Immunologic resistance after repeated botulinum toxin type a injections for facial rhytides. Ophthal Plast Reconstr Surg. 2006;22:239-240.

15. Lee SK. Antibody-induced failure of botulinum toxin type A therapy in a patient with masseteric hypertrophy. Dermatol Surg. 2007; 33(1 Spec No):S105-S110.

16. Dressler D, Wohlfahrt K, Meyer-Rogge E, Wiest L, Bigalke H. Antibodyinduced failure of botulinum toxin a therapy in cosmetic indications. Dermatol Surg. 2010;36 Suppl 4:2182-2187.

17. Stengel G, Bee EK. Antibody-induced secondary treatment failure in a patient treated with botulinum toxin type A for glabellar frown lines. Clin Interv Aging. 2011;6:281-284.

18. Greene P, Fahn S, Diamond B. Development of resistance to botulinum toxin type A in patients with torticollis. Mov Disord. 1994;9: 213-217.

19. Jankovic J, Schwartz K. Response and immunoresistance to botulinum toxin injections. Neurology. 1995;45:1743-1746.

20. Naumann M, Toyka KV, Mansouri Taleghani B, Ahmadpour J, Reiners K, Bigalke H. Depletion of neutralising antibodies resensitises a secondary non-responder to botulinum A neurotoxin. J Neurol Neurosurg Psychiatry. 1998;65:924-927.

21. Kranz G, Sycha T, Voller B, Kranz GS, Schnider P, Auff E. Neutralizing antibodies in dystonic patients who still respond well to botulinum toxin type A. Neurology. 2008;70:133-136.

22. Lange O, Bigalke H, Dengler R, Wegner F, deGroot M, Wohlfarth K. Neutralizing antibodies and secondary therapy failure after treatment with botulinum toxin type A: much ado about nothing? Clin Neuropharmacol. 2009;32:213-218.

23. Dressler D, Dirnberger G. Botulinum toxin antibody testing: comparison between the immunoprecipitation assay and the mouse diaphragm assay. Eur Neurol. 2001;45:257-260.

24. Aoki KR, Smith LA, Atassi MZ. Mode of action of botulinum neurotoxins: current vaccination strategies and molecular immune recognition. Crit Rev Immunol. 2010;30:167-187.

25. Froude JW, Stiles B, Pelat T, Thullier P. Antibodies for biodefense. MAbs. 2011;3:517-527.
Clinical, Cosmetic and Investigational Dermatology

\section{Publish your work in this journal}

Clinical, Cosmetic and Investigational Dermatology is an international, peer-reviewed, open access, online journal that focuses on the latest clinical and experimental research in all aspects of skin disease and cosmetic interventions. All areas of dermatology will be covered; contributions will be welcomed from all clinicians and

\section{Dovepress}

basic science researchers globally. This journal is indexed on CAS. The manuscript management system is completely online and includes a very quick and fair peer-review system, which is all easy to use. Visit http://www.dovepress.com/testimonials.php to read real quotes from published authors. 